\title{
P343: Management of hospital risks : between emergency and care quality in Algeria
}

\author{
D Zoughailech
}

From 2nd International Conference on Prevention and Infection Control (ICPIC 2013)

Geneva, Switzerland. 25-28 June 2013

\section{Introduction}

The stake represented by risks from care environment is not well perceived in Algeria. The absence of a regulatory framework; insufficiency of surveillance, prevention and control of healthcare-associated infections and the mismanagement of waste arising from care activities involving infectious risks are few illustrations about it.

\section{Objectives}

Establishing a diagnosis of the current risks in our hospitals and show the urgency of their care, Propose a quality approaches for risk reduction.

\section{Methods}

Our approach consists in analyzing surveys (Prevalence of healthcare associated infections and surgical-site infections, SSI), the practices audit and the reports made by our hospital hygiene unit during the two years 2011/2012 in Universitary hospital of Constantine.

\section{Results}

In terms of risk and quality of care, the nosocomial infection (NI) is currently one of the best "markers". According to our studies, the prevalence of NI was 14\% and that of SSI 9\%. We will record the endemicity of MRB (multi-resistant bacteria) and the emergence of vancomycin-resistant enterococci (VRE). We will discuss of the other insufficiencies, such as the behavior of health care professionals, about the very low adhesion rate to hand hygiene.

\section{Conclusion}

Finally, we will propose a quality system oriented on responsibility shared by managers, professionals, technical services staff and patients. This approach is subject

Department of medicine preventive and épidemiology , University Hospital of Constantine, Constantine, Algeria

\section{() Biomed Central}

to a structured program to protect patients, improve the working conditions of staff and reduce risks.

\section{Disclosure of interest}

None declared.

Published: 20 June 2013

doi:10.1186/2047-2994-2-S1-P343

Cite this article as: Zoughailech: P343: Management of hospital risks : between emergency and care quality in Algeria. Antimicrobial Resistance and Infection Control 2013 2(Suppl 1):P343.

Submit your next manuscript to BioMed Central and take full advantage of:

- Convenient online submission

- Thorough peer review

- No space constraints or color figure charges

- Immediate publication on acceptance

- Inclusion in PubMed, CAS, Scopus and Google Scholar

- Research which is freely available for redistribution 